\title{
Andragogical assumptions in the adult students' learning process to improve reading skills
}

\section{M.A. Yahui Huang Chang}

yahui.huang@uh.ac.cr

Facultad de Educación

Universidad Hispanoamericana

\begin{abstract}
The present study includes andragogy related topics applied in the adult teaching system in Costa Rican night schools. It comprises all background information and the purpose of the study, demonstrates the validity of the research and the realistic context the participants of the current study encounter in their academic organization. Also, contains the theories relevant to the Andragogical study and provides the reason the research problem under study exists. Terms such as andragogy, adult, adult learning were explained in detail using other important works from well-known investigators and educators. After these terms are clarified and understood, it becomes a tool for readers and future investigators interested in the area. Additionally, it connects this study to existing knowledge. Decisively, it includes the significant methodology for teachers working with adult students. Also, it shows which information was gathered to back up the study and indicates the nature of this qualitative research. Lastly, it shows the analysis of the obtained data. Accordingly, as conclusions and recommendations, it covers critical assumptions to help future investigators and teachers in the adult learning and teaching process.
\end{abstract}

Key Words: andragogy; adult learning; adult teaching; andragogical theories; adult education 


\section{Supuestos andragógicos en el proceso de aprendizaje de estudiantes adultos para mejorar la competencia lectora}

\section{RESUMEN}

El presente estudio incluye temas relacionados con la andragogía aplicados en el sistema de educación adulta en las escuelas nocturnas costarricenses. Comprende todos los antecedentes y el propósito del estudio, demuestra la validez de la investigación y el contexto realista que los participantes del presente estudio encuentran en su organización académica. Además, contiene las teorías relevantes para el estudio andragógico y proporciona la razón por la que existe el problema de investigación en estudio. Términos como andragogía, adulto, aprendizaje de adultos se explican en detalle al utilizar otras literaturas importantes de reconocidos investigadores y educadores. Una vez aclarados y comprendidos estos términos, se convierte en una herramienta para lectores y futuros investigadores interesados en el área. Además, la siguiente investigación conecta este estudio con el conocimiento existente. Finalmente, incluye la metodología significativa para los docentes que trabajan con estudiantes adultos. Además, muestra qué información se recopiló para respaldar el estudio e indica la naturaleza de esta investigación cualitativa. Asimismo, muestra el análisis de los datos obtenidos. En consecuencia, como conclusiones y recomendaciones, se cubre supuestos críticos para ayudar a futuros investigadores y maestros en el proceso de aprendizaje y enseñanza de adultos.

Palabras claves: andrología; enseñanza adulta; teorías andragógicas; aprendizaje adulto; educación adulta

Artículo recibido: 15 enero 2022 Aceptado para publicación: 08 febrero 2022 Correspondencia: yahui.huang@uh.ac.cr Conflictos de Interés: Ninguna que declarar 


\section{INTRODUCTION}

In Costa Rica, formal English lessons in elementary and secondary school started in 1994, when English was established as the basic subject matter. However, it was not put into practice until the Arias Sánchez government. At that period, there were not properly trained English teachers, which lead to the hiring of foreign language teachers for the only high schools at that moment, Liceo de Costa Rica, Liceo de Señoritas, Liceo San Luis Gonzaga and Instituto de Alajuela. (Marín, 2012, p.5) From that moment on, MEP (Ministry of Public Education) has created a series of syllabus to fit the distinctive necessities of the population. For instance, the latest 2016 version of the syllabus, includes aspects to improve all language skills.

As contrary to pedagogy, andragogy is focused on adult teaching, it is a learner-focused approach, based on the students' cognitive capacities. This theory has not been completely explored since teachers in Costa Rica are prepared to teach and interact with daytime adolescent students. However, adult students' population has grown due to different factors. Facilitators do not only face adolescent and young students, but also adult students, which create a demand for teachers to prepare themselves to be able to confront the adult population. Indisputably, andragogy can be contrasted with pedagogy by the dissimilar characteristics and the unalike approaches they require to instruct students in the most accurate way.

This population includes adults who are already part of the working society and receive an income to support their family; many of them are in their forties. These students have not received any formal education for an extremely long time. Thus, it is very hard for them to pick up where they have left in high school ten or twenty years ago to continue it. They struggle every time they go to school and get confused whenever they participate in a lesson, since adult brain's capacity is not as flexible, and the fresh information will not be processed the same way as in teenagers.

Students in the night school setting meet lots of difficulties to continue with their high school studies. UNESCO (2010) also portraits this: "Most high-income countries are close to universal secondary education, with a large share of the population progressing to the tertiary level, but marginalized groups still struggle and face further discrimination in the job market." (p. 16). Therefore, it is essential for teachers to encourage them employing accurate methodologies, focusing on students' needs. In the learning process, 
students are the major participants, so all the methods and approaches chosen and applied in the classroom should be student-centered. Adult learning is more effective when it involves solving problems that are significant to the learner's everyday experience. They find it easier to process information when they can relate it to their own knowhows.

It is imperative for educators to know and apply andragogy in order to improve student's performance and competence in the academic area. In pedagogy, the teacher plays the most important role in student's education process, as a guide. Nevertheless, in andragogy, students are the most important character in their own learning process. Thus, teachers' roles change in the adult teaching; teacher then ought to apply approaches that make learners feel comfortable and motivated to study.

The task that lies ahead is mostly focused on teachers. They must provide learners reliable schooling, to fulfill their needs and encourage them to keep pushing their goals in life. Therefore, proper training is required for teachers to do their best. As explained by Ranga Rao (2006): "The technical knowledge and skill can be developed in the teacher through training. Therefore, training is necessary for all type of teachers." (p. 14) The progress of a country depends on the students and the evolution of students depend on the teacher, which implies that the progress of a whole country relies on the teachers. On the contrary, the lack of accurate training leads to some educators' disinterest in the area. Most of the teachers in current night schools graduated from college with a secondary teaching diploma, which means they are qualified to tutor high schoolers. Nevertheless, these high schoolers are daytime students, thus, adolescents. The difference between the two population is clearly broad. This suggests that educators are not getting enough information to be able to perform adequately with adult students. Therefore, there is clearly no equality in terms of learning opportunities for adult students.

\section{Andragogy, A Theory of Adult Learning}

Certainly, andragogy, the art of helping adults learn, is not a new term.

As mentioned by Isenberg, in Applying Andragogical Principles to Internet Learning: "Before it was named, the art and science of adult learning was practiced as evidenced in by early writings about Socrates." (2007, p.14) Socrates had lots of students, whom he taught by conversing with them. In those conversations, Socrates took ingot account his pupils' prior knowledge and experiences in life to help them understand something. 
Recently, more and more adults have continued or started their education by attending to a night school. Indeed, whether done informally or formally, at school or at home, this situation has increased, which is why Costa Rican government has promoted the adult education system to encourage adult students. With rapid economic and technological change, the projections for increased adult education are convincing. Though, while adults can be readily found in organized and/or intentional educational experiences of various kinds, it is not immediately apparent how the educational experience can best be organized and delivered to the adult learner. Therefore, questions are asked for this singularity: Do adult students require unique new learning methodology? Do adult students have specific needs and that it should be personalized to produce more solid results? What are the best ways to provide them better educational experiences? Fortunately, Knowles's andragogy answers all questions.

It is known that there is no single technique that can apply to all students. Undeniably, it should be tailored to each student's needs and interests in order to produce the best results. Hence, it originated the necessity of a theory for adult teaching. Moreover, for any technique, methodology, or theory, there should be principles. Indeed, andragogy is not the exception. Listed by Knowles (2005), it collects six principles; “the learner's need to know, self-concept of the learner, prior experience of the learner, readiness to learn, orientation to learning, and motivation to learn." (p.3) Those principles are selfexplanatory and are effective to any kind of learner. Also, such principles are challenging to be managed without the assistance of an instructor. Teachers play an indispensable role in the learning process; they oversee orientation, instruction, monitor, and encourage learners.

Teaching provides endless challenges and opportunities for growth. The instructor for adult learners must not only communicate scholastic topics but also experiences and reallife situations. Adults have more experience in life, so, if they can see their real life reflected in the instructive context, they might feel more identified with the subject matter and the cognitive target will become more significant for them. This certainly helps them retain information for a long period of time. If the information is meaningful for the learner, it will be stored in the long-term memory. "Adult educators in the critical tradition envisage teachers and learners engaged in a collaborative cocreation of knowledge as they embrace a diversity of perspectives and experiences.” (p. 218), writes Stephen Brookfield 
(2005) in The Power of Critical Theory for Adult Learning and Teaching. This author mentions that the teacher should engage a collective creation of knowledge incorporating experiences from both teacher and student to improve scholar's proficiency.

\section{Self-Directed Learning}

Self-Directed Learning is the one where need from others is not necessary. For this kind of learning approach, students require more discipline and self-consciousness of what they want and why they are doing what they do. They must truly understand the main reason why they are retaking the studying process after all those years without even touching an academic book. Accordingly, most children do not have the capacity to be responsible for their education process and take care of their schedules and study methodologies. Children depend on their teacher to instruct them and be passive learners, but adults already recognize the reason they are learning, they become active apprentices. Smith (2009), along with two co-writers, support this in the study Emerging Adulthood published in the Handbook of Research on Adult Learning and Development: "At emerging adulthood, learning and development become the responsibility of the individual and prioritization of continued education and maturation requires selfdirectedness." (p. 34).

It is believed that this process is more effective since it is more significant to the student for, they oversee their learning involvement, which is motivating. Furthermore, as grownups, people have already started working, and might not have as much time as an adolescent to study. They must organize their time and learning may occur outside work and sometimes even outside of school. Subsequently, this self-directed process is more informal and commands self-monitoring. Many adults opt for this learning strategy because of the complicated working hours they handle. The role of the educator is not as important as in a formal context, the students look for help whenever they need it; if they do not demand help, the teacher would have no place in this process. "And because adult manage other aspects of their lives, they are capable of directing, or at least assisting in planning, their own learning." (p. 5), affirmed Merriam (2001) in The New Update on Adult Learning Theory.

There is not a single theory that can be applied to a certain group of learners. Some adult learners are extremely dependent on a teacher for monitoring and structure when some children are independent and can study effectively on their own. Even though the self- 
directed learning is designed mostly for adults, it can be fitting for another group of pupils. Hence, it is known that self-directed is not only useful for adults. Except, it is employed more by adults because of their daily routine and because of the experiences they have encountered during the process of growing up. Without a doubt, adults already have more experience in time management and schedule organization.

A major component for this is that students guide and programs his or her own learning. Emphatically, to undertake this, it is crucial to set goals and objectives for the learning progress. After a goal has been set, both learner and instructor have a direction and can go forward without getting lost during the process. The instructor ought to employ useful meaningful strategies to help students accomplish such goal. As stated in Psychology and Adult Learning: "Typically, a learning contract requires some kind of diagnosis of needs, followed by a specification of goals and objectives, the identification of learning strategies and resources, and the evaluation of progress." (Tennant, 2006. p. 9)

\section{Challenges of Teaching English in Costa Rica}

There are several important factors to consider as challenges in teaching English in secondary school. The most dominant is the quality of the teachers. Currently, many universities around Costa Rica are offering English Teaching major. This involves greater opportunities to enrich oneself as a teacher and receive adequate preparation to assume the responsibility of a foreign language teacher.

Although the universities offer appropriate training, the teachers who taught the lessons lacked sufficient skills to assume that responsibility. Therefore, since 2008, teachers of English teaching undergo a TOEIC test (Test of English for International Communication), conducted by the Costa Rican Cultural Center in North America, to diagnose the linguistic competence of these English teachers. That was a way to improve the proficiency of teachers in the area. This measure has had positive results, according to the article by Diaz (2016), of the Ministry of Education: 59,3\% of the teaching staff belong in the higher bands of the common frame of reference (C1 y B2), while in 2008, only the $33,7 \%$ reached that band. This implies a representative progress in the teaching of English in the country. According to the report of the State of Education of 2015: in 2014, there were more young teachers in English and Math, because near 70\% of them were under the age of 40 . The hiring of young teachers brings a great advantage to the 
area as new teachers are more informed of the current situation and can implement new and innovative teaching methods.

One aspect worth stating here, these programs include the same contents daytime high schools use. Although here is the discrepancy, adult students enrolled in night schools only have seven months to get ready for the MEP exam. Three months less than daytime students, but the same amount of content. This has been a difficulty for both teachers and students since they take classes/tutoring only three days per week, which is obviously not enough time to cover all the contents MEP is asking them to learn by the time they must apply the exam. Some students may pass the exams if they study hard and dedicate more extra time to school. Nevertheless, others may not have that privilege since they work and attend their family, which leave them almost no time to go to school and clarify all questions they might encounter when studying on their own.

\section{Theory of Andragogical Assumption}

Malcom Knowles, as the father of Andragogy, was considered for this part. His theories are appropriate for the purpose of the current paper and is the missing puzzle this study needs. Adult students require explanation to everything new they receive; that is the way how they understand. Once they get the explanation, they can accept it and start applying the theory. As adults grow, the brain functions differently from a child; accordingly, it becomes extremely hard for them to memorize things. For that matter, they learn by doing things. The task-based approach focuses on completing tasks, which is what adult population need. When they put the theory into practice, it would be easier to comprehend and to apply it in real contexts.

A distinguishing feature of these learners is that they are self-directed. Which means they can complete a test by themselves, the role of the teacher is only to be a facilitator. The teacher provides guidance only when needed and let students draw conclusions on their own. This way, adult pupils feel more independent and once they realize they can end academic tasks by themselves, it helps enhance their self-confidence.

Another vital feature is the experience students already have in their lives. These experiences help shape the way they understand and perceive academic matters. They have already made mistakes and can decide what is beneficial for them. The student has already become a social agent rather than a scholar, all the prior knowledge and necessities contribute identity them into real life investigators. Also, when receiving 
subjects in a class, they relate it to their personal life or job, which constructs a more meaningful learning process.

In terms of including andragogy into reading skills, adult students are more interested in reading topics that are associated to their personal life, job, or other aspects that affect their daily life. For this reason, the facilitators should prepare resources that are adequate for this population. When there is more interest, there is more knowledge acquisition.

\section{Sources/ Subjects of Study}

To gather information, two questionnaires were arranged; one for teachers who work in Educación Abierta, and the other one was applied to students who belong to this educational system. The teachers who participated in this process are educators who have been working in the Educación Abierta system for more than three years.

\section{Selection of Teaching Staff}

Evidently, MEP oversees the selection of the teaching staff accurate for the night school population. As indicated in the official webpage: "The Department of Human Resources of the Ministry of Public Education executes the processes related to the planning, promotion, recruitment, selection, appointment, training and evaluation of the MEP's employees." However, this selection process does not take experience into account, which means, any teacher with zero experience or knowledge about adult education can be a candidate for the English teacher position in any of the night schools around the country. The MEP grades teachers by assigning them scores, and categories based on their academic background and the credentials and diplomas they get from courses and majors they have participated before. For instance, a teacher graduated from the bachelor's degree obtains a MT4 as category, one graduated from the Licenciatura degree, gets a MT5, and the highest category is a MT6 which is a diploma course with a focus on English Teaching in first and second cycle. Moreover, if there are more diplomas and additional courses, the MEP will take them into account as what they call carrera profesional and add more points to the instructor's current score.

\section{English Teaching Syllabus}

The content in the high school syllabus and the one for the night school program has no difference. At the night school system, teachers use a similar syllabus and teach the identical contents. The only difference is the period; daytime school completes the contents from the syllabus in ten months, while nighttime schools of Educación Abierta, 
spend only seven months to finish the same number of contents to be prepared for the Bachillerato exam.

\section{CONCLUSIONS}

1. The main objective of the present paper is to gather Andragogical methodologies for teachers to improve adult students' reading skill in English. A limitation in the night school setting is that the students in meet lots of difficulties to continue with their high school degrees. Such complications might involve, social, financial, family, personal, and so on. Therefore, it is essential for teachers to encourage them employing accurate methodologies, focusing on student's needs. In the learning process, students are the major participants, so all the methods and approaches chosen and applied in the classroom should be student centered.

Besides, those students really need lots of support to remain in their learning process. Even when learners are already motivated by their necessity of getting the high school diploma, there are many external factors that affect them to drop out of school easily. Adult learning is more effective when it involves with solving problems that are significant to the learner's everyday experience.

The present study includes a chart with some Andragogical theories that educators can consider. Such theories indicate that in order to apply Andragogical assumptions into the educational environment, it is imperative to develop further investigations and cultivate more professionals specialized on Andragogical teaching strategies.

From the Andragogical point of view, a characteristic that differ adult students from young students is the need to know. Adult learners have already been in the society for a while and knows what they are facing every day. Therefore, their knowledge must be expanded for them to be able to do their daily tasks appropriately. Adults already know the function and benefits of school subjects, which makes it easier for them to learn since it is a decision they take, not one that is forced on them.

2. In the topic of identifying theoretical Andragogical assumptions for reading skill in adult students, there are a few concepts to be defined. It is important to look at the meaning of "adult." There are various definitions of adult. Biologically, individuals become adults when they reach the age they can reproduce, and there are physical changes in their body. Legally, people become adults when it is legal for them to vote, to get a driver's license, and so. Socially, people are considered adults when they 
perform adult-like tasks, working, being responsible for a family, and so on. Moreover, the Cambridge Online Dictionary states that adult means "a person or animal that has grown to full size and strength."

If the previous concept of adulthood is taken into consideration, then all college students will also be part of the adult population. So, university professors will also require formal training before taking any course. Undeniably, students from elementary school, high school, and college have unalike needs and require unlike teaching methodologies. Then, in order to teach, the educator should first be prepared and know how to get along with students. Unfortunately, the proper process is not done because there are very little study and guidance dedicated to teachers in this specific area. Difference between adults and adolescents, adults are responsible for their own life, and the decisions they take may affect them.

It requires learning orientation and willingness; this population are attending school on their own will. They recognize the importance of acquiring more knowledge in order to improve not only their personal life but also their professional space. Adult pupils already understand how enjoyable it is to learn when one already knows the benefits of educating and enlightening ones' mind to achieve the sensation of learning. Consequently, these population needs to be treated according to their age; otherwise, learning will become a hideous process for them. Also, adults learn from the experiences. They do not only have more experience in life than adolescents, but they also are more experienced in aspects like job, marriage, social life, and so on. Accordingly, professors should take advantage of that experience and make their learning process more pleasant. The instructor can relate the academic aspects to their life experiences and turn the contents into something meaningful for the adult learners.

3. The current paper remarks some Andragogical methodologies that can be adapted in adult education concerning reading skill in English. More importantly, it is the active participation of both students and teachers in the whole educational process that guarantees the success of Andragogy. A good foundation of instruction has characteristics, and Wlodkowski (2008) refers to those as expertise, empathy, enthusiasm, clarity, and cultural responsiveness. (p. 50)

In conclusion, from the Andragogical point of view, one characteristic that differ adult students from young students is the need to know. Adult learners have already been 
in the society for a while and knows what they are facing every day. Therefore, their knowledge must be expanded for them to be able to do their daily tasks appropriately. Adults already know the function and benefits of school subjects, which makes it easier for them to learn since it is a decision they take, not one that is forced on them.

4. When referring to the guidelines to incorporate andragogy into the techniques and methodologies in Educación Abierta, adult population must be the emphasis. Current guidelines are focused on teenagers, so even if there are some similarities, it is not a long-term solution for anyone involved in the didactic process. As active participants, Andragogical practices and stimulating activities in class are to be included into the teaching guideline.

The idea is not only to design the guideline but also have qualified teachers who can employ it in the real adult classrooms. It is also worth noting that the teachers ought to be competent for these positions; otherwise, it will be an unbearable experience for both teacher and students.

\section{RECOMMENDATIONS}

1. The Andragogical methodologies must be applied in the adult student classroom. It is not ethically or didactically appropriate to use rules or plans for teenagers on adults. Each populace is extremely dissimilar; wherefore, it is advocated to not treat them the same. While teenagers obtain new knowledge, adult students already have prior knowledge that needs to be structured to allow the creation of new experiences.

It is known that students, regardless their age, should be active participants in the learning process. Adult students should also be active participants in their own learning process. Hence, their learning process must include practices and interactive activities where they can test their understanding of the topic and boost their selfconfidence.

2. The purpose of identifying theoretical Andragogical assumptions is to improve students' language skills in general. These should become a practical tool for all teachers and people involved in the adult teaching-learning process. In addition, it needs to also provide a clear view of the attitudes and roles of the instructor and the learner. Apart from that, the assumptions are able to assist educators who are linked to the adult education system. The assumptions are going to provide clear guidelines and tips to decide what is suitable for achieving didactic goals. 
3. As mentioned in chapter four, the teaching staff is not different from the daytime teachers. MEP should carefully select the educators who manage or at least know about Andragogy to instruct adult students. There should be some requirements to work with this population and trainings that increase teachers' knowledge in the area. On the other hand, the syllabus should be adapted to the needs of adults' learners rather than using the same for younger students.

Unquestionably, most of the student population in this system possess a full-time job to support their families. These jobs they have, are rarely highly paid. Thus, the Costa Rican Ministry of Labor ought to encourage adults to study by providing jobs opportunities that are more profitable once they finish the degree. Furthermore, the local board of education and the municipalities can offer scholarships for those who want to make some changes in their lives.

4. Designing guidelines to incorporate andragogy into the techniques and methodologies in adult education, MEP plays an essential role. Currently, there are no academic guidelines to be followed. Teachers use the same syllabus and teaching methodology proposed for daytime teenage students. Therefore, it is urgent, for the good of adult learners, to create a syllabus based on Andragogical theories. The MEP should also adapt or create a brand-new program for adult students that includes all the Andragogical aspects teachers must know to be prepared.

\section{REFERENCES}

Brookfield, S. D. (2005). The Power of Critical Theory for Adult Learning and Teaching. Berkshire: Open University Press.

Knowles, M. S., Elwood F. H. III, and Swanson R. A. (2005). The Adult Learner: Sixth Edition. London: Elsevier.

Marín, E. (2012) Cronología de la enseñanza de inglés en Costa Rica durante el siglo XX. San José: Revista Comunicación: Instituto Tecnológico de Costa Rica.

Merriam, Sharan B. (2001). The New Update on Adult Learning Theory. San Francisco: Jossey-Bass.

Ministerio de Educación Pública de Costa Rica. (2016). Educación para personas jovenes y adultas. San José: MEP. Available in: http://www.mep.go.cr/educacion-depersonas- jovenes-y-adultas 
Ministerio de Educación Pública de Costa Rica. (2016). ABC de los Programas de Educación Abierta. San José: MEP. Available in: https://www.mep.go.cr/sites/default/files/blog/ajduntos/abc-programaseducacion- abierta-dgec.pdf

Ranga Rao, R. \& Bhaskara Rao, D. (2006). Methods of Teacher Training. New Delhi: Discovery Publishing House.

Smith, C. M. (2009). Handbook of Research on Adult Learning and Development. New York: Routledge.

Tennant, M. (2006). Psychology and Adult Learning. London: Routledge; 2006.

UNESCO. (2010) Informe mundial sobre la diversidad cultural: invertir en la diversidad cultural y el diálogo intercultural. Organización de las Naciones Unidas para la Educación, la Ciencia y la Cultura.

Wlodkowski, R. J. (2008). Enhancing Adult Motivation to Learn. $3^{\text {rd }}$ ed. San Francisco: Jossey-Bass. 